\title{
Impact of Different Level of Level of Irrigation and Antitranspirant upon Wheat (Triticum aestivum L.) Growth and Yield under Soil Application of Hydrogel
}

\author{
Vikram K. Pallekonda ${ }^{1 *}$, Richa Sharma ${ }^{1 *}$, Sameer Daniel ${ }^{2}$, \\ Saad S. Burondkar ${ }^{1}$ and Anusha N. Reddy ${ }^{1}$
}

${ }^{1}$ Department of Biological sciences, ${ }^{2}$ Department of Silvi culture and Agroforestry, Sam Higginbottom University of Agriculture, Technology and Sciences, Allahabad 211007, UP, India

*Corresponding author

\section{Keywords}

Hydrogel, Chitosan, Water scarcity, Levels of irrigation

Article Info

Accepted:

24 August 2018 Available Online: 10 September 2018

\section{A B S T R A C T}

Suitable Irrigation to the crop is an important attribute for potential yield of among various crops. Present scenario of weather fallouts at destructing besides allocating rainfall pattern leading to different water stress. In some part of U.P, especially eastern U.P will face in temperature ( 3 to $5^{\circ} \mathrm{C}$ up to 2050 ) as per SAPCC, due to increase in rate of transpiration that will rise demand. To cope up with coming situation the experiment was conducted at Central Agricultural field, Sam Higginbottom University of Agriculture, Technology \& Sciences, U.P on wheat variety (HD-2967). Hydrogel and Chitosan were taken under different concentration to evaluate the efficacy of hydrogel on wheat (Triticum aestivum L.) Physio-biochemical and yield under different levels of Irrigation and Chitosan. Absorbing the water and retaining water in the soil and by reducing the loss of water through stomata by forming a layer of waxy coating, is the aspect to be considered to deal with such arriving future. Superabsorbent polymer can absorb large quantities of water and retain in soil and Antitranspirant may reduce the loss of water via transpiration.Hydrogel $(50 \%)$ and Chitosan $(100 \%, 75 \%$ and $50 \%)$ with twenty-five treatments and three replications along with control were laid out in randomized block design Result on Growth and Yield under soil application of Hydrogel was observed Treatment $\mathrm{T}_{1}(100 \% \mathrm{HG}$ and $100 \%$ CHT) showed best results, however $T_{2}$ was statistically at par with $T_{1}$, whereas comparing with control $\mathrm{T}_{0}(100 \%$ IR $70 \mathrm{Lit}+\mathrm{NO} \mathrm{SAP}+\mathrm{NO}$ AT.

\section{Introduction}

Water is necessary for plant growth and development as it is involved in various physiological functions and is essential for different metabolic activities (Saeedipour, 2012). It has been said that water stress is considered to be most important among various environmental factors that drastically reduce plant production (European plant science organisation, 2005).

Climate change and global warming has destructing the available natural resources and 
agriculture (Paul, 2000). The change in pattern of precipitation it would directly affects the water resources in the concerned region. If the frequency and quality of rainfall changes that it alters the stream flows pattern and demands especially in agriculture, soil moisture and ground water reserves (Dore, 2005). Such increasing in temperature and low rainfall UP will face rise in temperature (2-4.5) and water scarcity condition, which is directly, effects on agriculture production (SAPCC, 2014). In the areas of India affected with water stress were declining half of its potential yield comparing with irrigated areas (GoP, 2010).

Wheat (Triticum aestivum L.) is an essential grain food component and is a very important commodity among cereal crops (Montazeri et al., 2005). Demand of the wheat is increasing gradually due to growing world population and millions of hectares of agriculture land are being lost every year in India due to stresses (Ashraf et al., 2004).

Water requirement of wheat plant is estimated as $450-650 \mathrm{~mm} / \mathrm{ha}$. Due to current water shortage issues, it is essential that the water use efficiency (WUE) of wheat be improved, while maintaining, or potentially increasing, grain yields (Shin et al., 2012). There are various management practices through which water soil relationship can be maintained to make plant withstand water stress condition.

The use of water absorbing polymers (i.e., hydrogels) or superabsorbent polymers (SAPs) such as polyacrylates cross-linked with polyacrylamides (PAM) can effectively improve the top soil's ability to store water available for plant growth and production (Yu et al., 2011), and reduce seepage of water, and fertilizer and heavy metal leaching down the soil profile (Qu and Varennes, 2009). It was designed specifically to perform in tropical and sub-tropical conditions of the country. Similar products of foreign origin introduced and tried in India. Antitranspirants are chemical compounds applied to plants to reduce transpiration and maintain high plant water status Chitosan is an antitranspirant compound that has proved to be effective in many crops (Karimi et al., 2012) and can help to preserve water resources use in agriculture (Bittelli et al., 2001).

Under chitosan application plant reacts to water deficit with a rapid, abscisic acid (ABA)-mediated closure of stomata bringing down rate of transpiration (Pospisilova et al., 2003). The objective of this study was to understand the relationship of hydrogel for better growth and biochemical parameters of wheat under different level of irrigation and chitosan.

\section{Materials and Methods}

Present study was conducted central agricultural field of SHUATS as per the purpose of study experiment was conducted based on surface irrigation to create water deficit condition for Wheat variety (HD2967), and experiment has undertaken with different irrigation levels \& chitosan. Over all 25 treatments has been undertaken with soil application hydrogel (7kg/ha). Different biochemical parameters have been recorded \& statistically analysed during the course of study (Table 1).

\section{Results and Discussion}

For plant height which were treated with Hydrogel and Chitosan are showing better result in comparison to water deficit condition. When compared with Control (100\% IR 70 Lit +NO SAP +NO AT) (35.62). Maximum plant height was observed in $\mathrm{T} 1(77.96 \mathrm{~cm})$ followed by T2 $(73.60 \mathrm{~cm})$, T3 $(72.66 \mathrm{~cm}), \mathrm{T} 4$ $(70.44 \mathrm{~cm})$, T5 $(69.48 \mathrm{~cm})$, T6 $(66.80 \mathrm{~cm})$, T7 $(64.45 \mathrm{~cm})$, whereas, Minimum plant height was observed in T24 $(56.48 \mathrm{~cm})$ Table 2. 
Hydrogel have been reported to increase the activity of cell division, cell expansion and cell elongation, ultimately leading to an increased plant height (Singh et al., 2015). Similar results have been reported by (Sivalapan, 2001) in soybean and (Kumaran et al., 2001) in tomato. For Number of Tillers (per hill) all the treatments under water deficit condition Over the stress treatments, stress imposed at vegetative caused decline of $19.11 \%$ in tillers as compared to non-stresses condition. When compared with Control (100\% IR 70 Lit +NO SAP +NO AT) (6.56). Maximum Number of Tillers was observed in T1 (11.20 per/hill) followed by T2 (7.33 per/hill), T3 (7.27 per/hill), T4 (6.93 per/hill), T5 (6.60 per/hill), T6 (6.60 per/hill), whereas, Minimum Number of Tillers was observed in T24 (4.87 per/hill) Table 2. Similar to present findings (Kimurto et al., 2003) and (Baque et al., 2006) have reported that water stress at tillering or at booting significantly affected the formation of tillers in wheat. For flag leaf length and flag leaf width all the treatments under water deficit condition. when compared with Control (100\% IR 70 Lit +NO SAP +NO AT) (11.34) Maximum Flag Leaf Length was observed in $\mathrm{T} 1(14.40 \mathrm{~cm})$ followed by $\mathrm{T} 2$ $(13.24 \mathrm{~cm})$, T3 $(12.84 \mathrm{~cm}), \mathrm{T} 4(12.54 \mathrm{~cm}), \mathrm{T} 5$ $(11.94 \mathrm{~cm})$, T6 (11.53), T7 (11.46 cm), whereas, Minimum Flag Leaf Length was observed in T24 $(7.93 \mathrm{~cm})$ Table 2 compared with Control (100\% IR 70 Lit +NO SAP +NO AT) (2.02).

Maximum Flag Leaf Width was observed in T1 $(1.73 \mathrm{~cm})$ followed by T2 $(1.66 \mathrm{~cm}), \mathrm{T} 3$ $(1.62 \mathrm{~cm})$, T4 $(1.57 \mathrm{~cm})$, T5 $(1.49 \mathrm{~cm})$, T6 $(1.46 \mathrm{~cm})$, T7 $(1.42 \mathrm{~cm})$, whereas, Minimum Flag Leaf Width was observed in T24 (1.01 $\mathrm{cm})$ Table 2. The decreasing graph in grain number was linked with reduced leaf area and lower photosynthesis as outcome of drought stress (Fischer et al., 1980). For spike length per spike and number of spikelet's per spike all the treatments which were treated with
Hydrogel and Chitosan were showing better result in comparison to water deficit condition. When compared with Control (100\% IR 70 Lit +NO SAP +NO AT) (6.68). Maximum spike length was observed in $\mathrm{T} 1(11.25 \mathrm{~cm})$ followed by T2 $(7.83 \mathrm{~cm}), \mathrm{T} 3(7.53 \mathrm{~cm}), \mathrm{T} 4$ $(7.26 \mathrm{~cm})$, T5 $(6.99 \mathrm{~cm})$, T6 $(6.96 \mathrm{~cm})$, T7 $(6.89 \mathrm{~cm})$, whereas, Minimum Spike Length was observed in T24 $(5.41 \mathrm{~cm})$ Table 3 compared with Control (100\% IR 70 Lit +NO SAP +NO AT) (11.56). Number of Spikelet's was observed in T1 (16.07 per spike) followed by T2 (15.33 per spike), T3 (14.07 per spike), T4 (13.73 per spike), T5 (13.53 per spike), T6 (13.40 per spike), T7 (12.13 per spike), whereas, Minimum Number of Spikelet's was observed in T24 (8.40 per spike) (Table 3).

The decrease in stem height and ear length due to water stress has been reported earlier in wheat (Iqbal et al., 1999). For yield parameters grain yield, 1000 grain weight all the treatments in which Hydrogel and chitosan is applied were showing better results in comparison to water deficit condition Maximum Grain yield was observed in T1 (32.65 q/ha- $\left.{ }^{-1}\right)$ followed by T2 (24.49 q/ha- 1), T3 (22.47 q/ha- 1), T4 (21.42 q/ha- 1), T5 (20.83 q/ha- 1), T6 (20.42 $\left.\mathrm{q} / \mathrm{ha}^{-}{ }^{1}\right), \quad \mathrm{T} 7 \quad\left(19.56 \mathrm{q} / \mathrm{ha}^{-}{ }^{1}\right) \quad$ whereas, Minimum Grain Yield was observed in T24 (8.67 $\mathrm{q} / \mathrm{ha}^{-}$1) Table 3. Maximum Test Weight was observed in T1 (42.81 gm) followed by T2 (32.35 gm), T3 (31.45 gm), T4 (29.16 gm), T5 (28.56 gm), T6 (28.36), T7 (28.00 gm) whereas, Minimum Test Weight was observed in T24 (17.34 gm) Table 3 . The results of many researches show that drought stress at different stages of the growth wheat under different levels Irrigations and Chitosan. Lead to a reduction in the yield of biomass, grain yield, harvest index and grain yield components wheat under different levels Irrigations and Chitosan (Gooding et al., 2003; Garcia et al., 2003 and Zaharieva et al., 2001). 
Table.1 Treatment details

\begin{tabular}{|c|c|}
\hline Treatments & Treatment combination \\
\hline $\mathrm{T}_{0}$ & 100\% IR 70 Lit +NO SAP +NO AT \\
\hline $\mathbf{T}_{1}$ & $80 \%$ IR $(56 \mathrm{Lit})+100 \% \mathrm{AT}(250 \mathrm{ppm})+50 \% \mathrm{SAP}(0.2 \mathrm{gm})$ \\
\hline $\mathbf{T}_{2}$ & $80 \% \mathrm{IR}(56 \mathrm{Lit})+100 \% \mathrm{AT}(250 \mathrm{ppm})+\mathrm{NO}$ SAP \\
\hline $\mathbf{T}_{3}$ & $80 \%$ IR (56 Lit) $+75 \%$ AT $(187 \mathrm{ppm})+50 \% \mathrm{SAP}(0.2 \mathrm{gm})$ \\
\hline$\overline{T_{4}}$ & 80\%IR 56 Lit + 75\%AT (187ppm) + NO SAP \\
\hline $\mathbf{T}_{5}$ & $80 \%$ IR (56 Lit) +50\%AT (125ppm) + 50\%SAP (0.2 gm) \\
\hline $\mathrm{T}_{6}$ & $80 \%$ IR $(56$ Lit $)+50 \%$ AT $(125 \mathrm{ppm})+$ NO SAP \\
\hline $\mathbf{T}_{7}$ & $80 \%$ IR $(56$ Lit $)+$ NOAT +50\%SAP $(0.2 \mathrm{gm})$ \\
\hline $\mathbf{T}_{8}$ & $80 \%$ IR (56 Lit) + NOAT +NO SAP \\
\hline $\mathrm{T}_{9}$ & $60 \% \mathrm{IR}(42 \mathrm{Lit})+100 \% \mathrm{AT}(250 \mathrm{ppm})+50 \% \mathrm{SAP}(0.2 \mathrm{gm})$ \\
\hline$\overline{T_{10}}$ & $60 \%$ IR (42 Lit) +100\%AT (250ppm) + NO SAP \\
\hline$T_{11}$ & $60 \%$ IR (42 Lit) $+75 \%$ AT $(187 \mathrm{ppm})+50 \% \mathrm{SAP}(0.2 \mathrm{gm})$ \\
\hline $\mathbf{T}_{12}$ & $60 \%$ IR (42 Lit) +75\%AT (187ppm) + NO SAP \\
\hline$T_{13}$ & $60 \%$ IR (42 Lit) $+50 \%$ AT $(125 \mathrm{ppm})+50 \% \mathrm{SAP}(0.2 \mathrm{gm})$ \\
\hline$\overline{T_{14}}$ & $60 \%$ IR (42 Lit) +50\%AT (125ppm) +NO SAP \\
\hline$\overline{T_{15}}$ & $60 \% \mathrm{IR}(42 \mathrm{Lit})+\mathrm{NOAT}+50 \% \mathrm{SAP}(0.2 \mathrm{gm})$ \\
\hline$T_{16}$ & $60 \%$ IR (42 Lit) + NOAT+NO SAP \\
\hline$T_{17}$ & $40 \% \mathrm{IR}(28 \mathrm{Lit})+100 \% \mathrm{AT}(250 \mathrm{ppm})+50 \% \mathrm{SAP}(0.2 \mathrm{gm})$ \\
\hline $\mathrm{T}_{18}$ & 40\%IR (28 Lit) + 100\%AT 250ppm + NOSAP \\
\hline $\mathrm{T}_{19}$ & $40 \%$ IR (28 Lit) $+75 \%$ AT $(187 \mathrm{ppm})+50 \% \mathrm{SAP}(0.2 \mathrm{gm})$ \\
\hline $\mathbf{T}_{20}$ & 40\%IR (28 Lit) +75\%AT (187ppm) +NO SAP \\
\hline $\mathbf{T}_{21}$ & $40 \%$ IR $(28$ Lit $)+50 \%$ AT $(125 \mathrm{ppm})+50 \% \mathrm{SAP}(0.2 \mathrm{gm})$ \\
\hline $\mathbf{T}_{22}$ & 40\% IR (28 Lit) +50\%AT (125ppm) +NO SAP \\
\hline $\mathrm{T}_{23}$ & 40\%IR (28 Lit) +NOAT +50\% SAP (0.2 gm) \\
\hline $\mathrm{T}_{24}$ & $40 \%$ IR (28 Lit) +NOAT+ NOSAP \\
\hline
\end{tabular}


Table.2 Efficacy of Pusa hydrogel on plant height $(\mathrm{cm})$, number of tillers (per hill), flag leaf length $(\mathrm{cm})$ and flag leaf width $(\mathrm{cm})$ of wheat under different levels of irrigation and chitosan

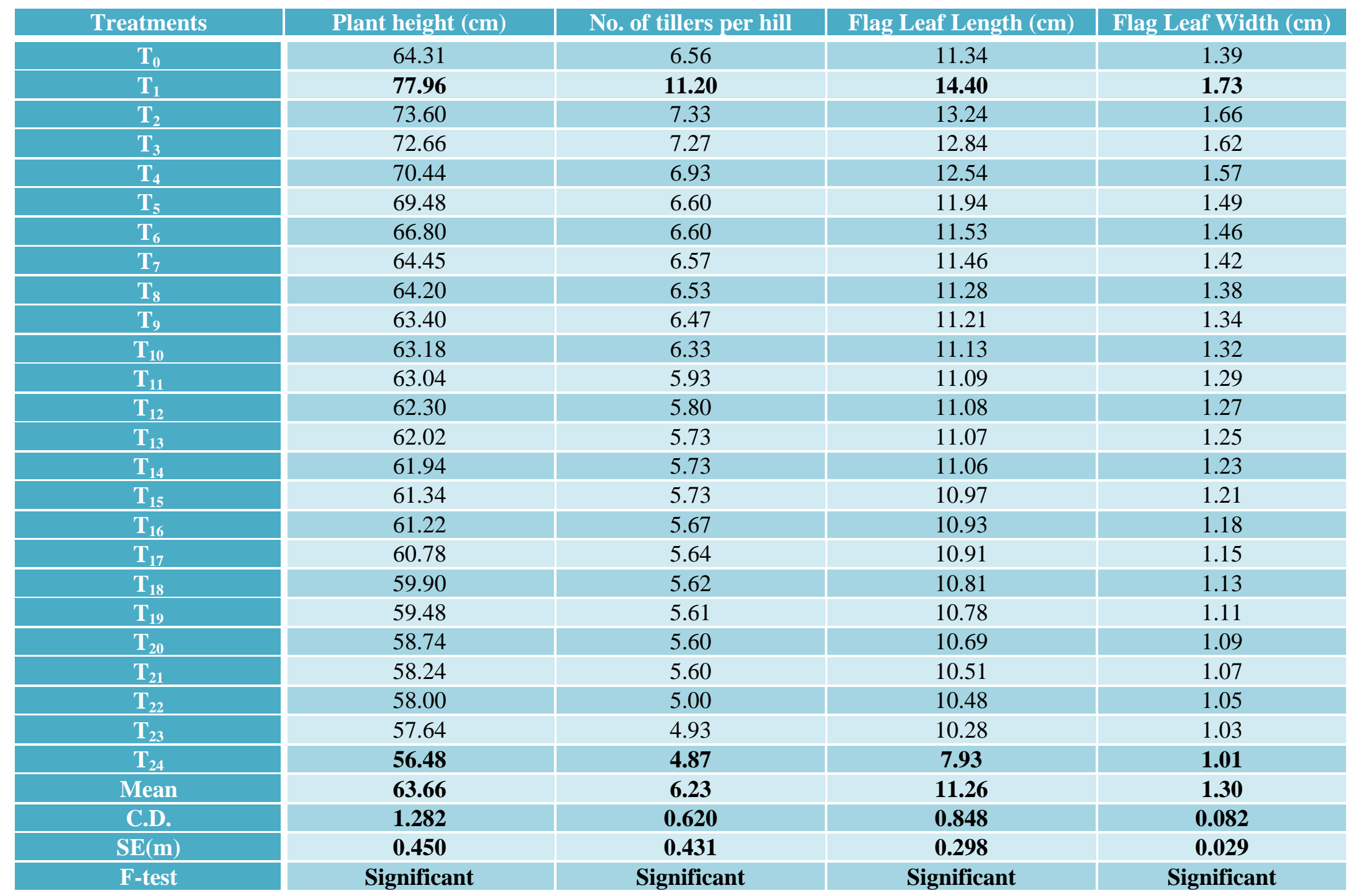


Table.3 Efficacy of hydrogel on Spike length $(\mathrm{cm})$, Number of spikelet (per spike), grain yield (q/ha), harvest index (\%) of wheatunder different levels of irrigation and chitosan

\begin{tabular}{|c|c|c|c|c|}
\hline Treatments & Spike length (cm) & Number of spikelet's/spikes & Grain yield (q/ha- 1$)$ & Harvest index (\%) \\
\hline $\mathbf{T}_{0}$ & 6.68 & 11.56 & 20.19 & 411.76 \\
\hline $\mathbf{T}_{1}$ & 11.25 & 16.07 & 32.65 & 523.82 \\
\hline $\mathbf{T}_{2}$ & 7.83 & 15.33 & 24.49 & 481.19 \\
\hline $\mathbf{T}_{3}$ & 7.53 & 14.07 & 22.47 & 468.3 \\
\hline $\mathrm{T}_{4}$ & 7.26 & 13.73 & 21.42 & 441.21 \\
\hline $\mathbf{T}_{5}$ & 6.99 & 13.53 & 20.83 & 423.18 \\
\hline $\mathbf{T}_{6}$ & 6.96 & 13.40 & 20.42 & 421.13 \\
\hline $\mathbf{T}_{7}$ & 6.89 & 12.13 & 19.56 & 415.29 \\
\hline $\mathrm{T}_{8}$ & 6.57 & 11.40 & 18.83 & 408.15 \\
\hline $\mathbf{T}_{9}$ & 6.55 & 11.20 & 18.74 & 407.85 \\
\hline $\mathbf{T}_{10}$ & 6.41 & 11.00 & 18.17 & 406.62 \\
\hline$T_{11}$ & 6.34 & 10.80 & 17.67 & 404.23 \\
\hline $\mathbf{T}_{12}$ & 6.32 & 10.73 & 17.33 & 400.99 \\
\hline$T_{13}$ & 6.27 & 10.73 & 17.24 & 396.69 \\
\hline $\mathbf{T}_{14}$ & 6.27 & 10.67 & 17.02 & 395.29 \\
\hline$T_{15}$ & 6.26 & 10.63 & 16.83 & 395.24 \\
\hline$T_{16}$ & 6.24 & 10.60 & 16.17 & 393.65 \\
\hline$T_{17}$ & 6.08 & 10.53 & 16.12 & 390.26 \\
\hline$T_{18}$ & 5.95 & 10.40 & 15.17 & 389.91 \\
\hline$T_{19}$ & 5.89 & 10.27 & 14.93 & 389.67 \\
\hline $\mathbf{T}_{20}$ & 5.84 & 9.27 & 14.54 & 388.21 \\
\hline $\mathbf{T}_{21}$ & 5.72 & 9.13 & 14.39 & 387.74 \\
\hline $\mathbf{T}_{22}$ & 5.61 & 9.13 & 14.33 & 385.31 \\
\hline $\mathbf{T}_{23}$ & 5.59 & 8.93 & 14.24 & 383.88 \\
\hline $\mathbf{T}_{24}$ & 5.41 & 8.40 & 8.67 & 302.83 \\
\hline Mean & 6.59 & 11.35 & 18.10 & 399.42 \\
\hline C.D. & 0.251 & 0.154 & 77.172 & 2.191 \\
\hline $\mathrm{SE}(\mathrm{m})$ & 0.088 & 0.546 & 27.103 & 0.770 \\
\hline F-test & Significant & Significant & Significant & Significant \\
\hline
\end{tabular}


The results of other researchers also show that harvest index will decrease in the treatments under drought stress due to the effect of drought stress on Economical yield (Gebeyehu, 2006).

Under Agro climatic condition of Allahabad This study may conclude that $T_{1}$ is performing best for all the absorbed parameters with maximum yield $\left(32.65 \mathrm{q} / \mathrm{ha}^{-1}\right)$ Minimum performance was showed by $\mathrm{T}_{24}$ yield (8.67q/ha $\left.{ }^{-1}\right)$. Whereas in Proline, Superoxide dismutase under stress condition treatments are showing better in $\mathrm{T}_{24}$ than $\mathrm{T}_{1}$. Recommendation: $\mathrm{T}_{1}, \mathrm{~T}_{2}, \mathrm{~T}_{3}, \mathrm{~T}_{4}, \mathrm{~T}_{5}, \mathrm{~T}_{6}, \mathrm{~T}_{7}$ from all treatments are performing well, according to requirement and retention capacity of the soil any of these treatments can be adopted by the farmer.on the basis of cost benefit analysis following treatments are performing better comparison to $\mathrm{T}_{0}$, thus on the basis of soil condition and availability of water any of these can be adopted by the farmer.

\section{References}

Ashraf, M. and Harris, P.J.C., Potential biochemical indicators of salinity tolerance in plants. Plant Sci., 166: 3-16 (2004).

Baque, M.D.A., Karim, M.D.A., Hamid, A and Tetsush, H., (2006). Effects of fertilizer potassium on growth, yield and nutrient uptake of wheat (Triticum aestivum) under water stress conditions. South Pacific Stud., 27: 25-35.

Bittelli, M., Flury, M., Campbell, G.S., Nichols, E.J., 2001. Reduction of transpiration through foliar application of chitosan. Agric. Forest Meteorol. 107, 167-175.

Chartzoulakis K., Michelakis N. and Vougioukalou E., 1991, Growth and production of kiwi under different irrigation systems Fruits 46 (1):75-81.
Davenport D. C., Hagan R. M. and Martln P. E., 1969, Antitranspirant uses and effects on plant life california turfgrass culture VOL 19: 4.

Dore MHI. 2005. Climate change and changes in global precipitation patterns: what do we know? Environmental International 31:1167-1181.

European Plant Science Organisation. (2005). http://www.epsoweb.org.

FAO. 2009. FAOSTAT statistical database. Rome (available at faostat.fao.org)

Farshadfar, E., Farshadfar, M. and Sutka, J., Combining ability analysis of drought tolerance in wheat over different water regimes (2000). Acta Agron. Hung. 48: 353-361.

Fischer R, Turner N \& Kramer P (1980) Influence of water stress on crop yield in semiarid regions. In: Turner NC \& Kramer PJ (eds) Adaptation of plants to water and high temperature stress. Wiley, New York, pp. 323-339.

Garcia, D., Moral, L.F., Rharrabt, Y., Villegas, D and Royo, C (2003). Evaluation of grain yield and its components in durum wheat under Mediteranean condition, Agronomy Journal. 95: 266-274.

Gebeyehu, S (2006). Physiological response to drought stress of common bean (Phaseolus vulgaris L.) genotypes differing in drought resistance, Ph.D. Thesis. University of Giessen. Germany.

Gooding, M. J., Ellis, R.H., Shewry P. R and Schofield, J. D (2003). Effects of restricted water availability and increased temperature on grain formation, drying and quality of water wheat, Journal of cereal Sciences 37: 295-309.

GoP (Government of Pakistan). 2010. Discussion paper for people's five-year development plan 2010-1015. Planning Commission, Islamabad, Pakistan. 
Huang, M. B., Shao, M. A., Zhang, L. \& Li, Y. S. 2003, Water use efficiency and sustainability of different long-term crop rotation systems in the Loess Plateau of China.Agric. Soil \& Tillage Res. 72, 95-104, doi: 10.1016/S01671987(03)00065-5.

Iqbal, M., Ahmed, I., Ahmed, M., Sadiq and Ashraf M.Y (1999). Yield and yield components of durum wheat (Triticum durum) as influenced by water stress at various growth stages. Pak journal of Biological sciences 2: 1438-1440.

Karimi, M.M. \& Siddique, H.M. (1991). Crop growth and relative growth rate of oldand modern wheat cultivars. Australian Journal Agricultural Research, 42, 13-22

Kimurto, P.K., Kinyua M.G and Njoroge, J.M (2003). Response of bread wheat genotypes to drought simulation under a mobile rain shelter in Kenya. African Crop Science Journal, 6: 329-344.

Kumaran, S.S., Natrajan, S., Muthvel, I and Sathiayamurthy, V.A (2001). Efficacy of graded doses of polymers on processing quality of tomato cv. $\mathrm{CO} 3$. Journal of Madras Agriculture, 88(4-6): 298-299.

Montazeri M, Z and E, Baghestani M.A. 2005. Weeds and their control in wheat fields of Iran, first ed. Agric. Res. Edu. Org. Press, Tehran.

Nagarajan, R. Drought Assesment Monitoring Management and Resource Conservation; Capital Publishing Company, New Delhi, 2003 pp-312.

Paul, St and MN Approved methods of American Association of Cereal Chemists AACC (2000). The American Association of Cereal Chemists. Inc.,

Pospíšilová, J: Participation of phytohormones in the stomatal regulation of gas exchange during water stress. - Biol. Plant. 46: 491-506, 2003.
Postel, S and L. and Wolf, A and T., 2001, "Dehydrating Conflict" Foreign Policy. 126: 60-67.

$\mathrm{Qu}$, G., and A. Varennes. 2009. Use of hydrophilic insoluble polymers in the restoration of metal-contaminated soils. Appl. Environ. Soil Sci. 2009:1-8. doi:10.1155/2009/790687

Saeedipour, S. 2012. Effect of post-anthesis water deficit on yield and some physiological parameters on two wheat cultivars. Afr. J. Agric. Res. 7: 34463452.

Scandalios, J and G. (1993). Plant Physiol. 101(1), 7-12.

Schewe, J. 2014, Multimodel assessment of water scarcity under climate change Proceedings of the National Academy of Sciences 111, 3245-3250.

Shin JH, Noh EH, Son JE., 2012, Transpiration, growth, and water use efficiency of paprika plants (Capsicum annuum L.) as affected by irrigation frequency. Hortic. Environ. Biote; 53(2): 129-134.

Singh, S.P (2015). Effect of Irrigation Schedule, Mulching and Hydrogel on Wheat (Triticum aestivum L.), Ph.D. Thesis. Banaras Hindu Univ. India.PA12011.

Sivapalan, S (2001). Effect of a polymer on growth and yield of soybeans (Glycine max) grown in a coarse textured soil. Proceedings Irrigation. Regional Conference, Pp. 93-99, Toowoomba, Queensland, Australia.

SPACC-Uttar Pradesh State Action Plan on Climate Change. Department of Environment (with support from giZ and CTRAN Consulting): CNTR NO 83181079

Success Story No. 14 lCN: 101/2012.

Tambussi, E. A., Bort, J., and Araus, J. L. (2007). Water use efficiency in C3 cereals under Mediterranean conditions: a review of physiological aspects. Ann. 
Appl. Biol. 150, 307-321. doi: 10.1111/j.1744-7348.2007. 00143.x

Wang, Y.T., and L.L. Gregg. 1989. Hydrophilic polymers- their response to soil amendments and effect on properties of a soilless potting mix. $J$. Am. Soc. Hortic. Sci. 115:943-948.

Yu, J. I. Shainberg, Yand L. Yan, J and G. Shi, G and J. Levy, and A.I. Mamedov.
2011, Superabsorbents and semiarid soil properties affecting water absorption. Soil Sci. Soc. Am. J. 75:2305-2313. doi:10.2136/sssaj2010.0397.

Zaharieva, M., Gaulin, E., Havaux, M., Acevedo, E and Monneveux, P (2001). Drought and heat responses in the wild wheat relative Aegilops geniculata Roth, Crop Science. 14: 1321-1329.

\section{How to cite this article:}

Vikram K. Pallekonda, Richa Sharma, Sameer Daniel, Saad S. Burondkar and Anusha N. Reddy. 2018. Impact of Different Level of Level of Irrigation and Antitranspirant upon Wheat (Triticum aestivum L.) Growth and Yield under Soil Application of Hydrogel. Int.J.Curr.Microbiol.App.Sci. 7(09): 3352-3360. doi: https://doi.org/10.20546/ijcmas.2018.709.416 